\title{
PENGARUH KOMPETENSI, LINGKUNGAN KERJA DAN KOMPENSASI TERHADAP KINERJA GURU TK DI WILAYAH II KECAMATAN PESANGGRAHAN
}

\author{
Hendri Jopanda \\ Program Studi Manajemen Universitas Satya Negara Indonesia \\ eMail : hjopanda@yahoo.com
}

\begin{abstract}
In the overall educational process, teachers are the dominant determinant in education because teachers are professional educators with the primary task of educating, teaching, guiding, directing, training, assess and evaluate students. A professional teacher is charged with a number of requirements, among others qualified professional education, scientific competence according they are engaged in, the ability to communicate well with their students, have a creative spirit and productive, has a work ethic and a commitment to the profession and always conduct self-development continuously. However, in practice there are still often found limitations both individually and institution. The purpose of this research is to know the effect of competence, work environment and compensation on the performance of kindergarten teachers in region II Pesanggrahan.

The research used survey methods by distributing questionnaires. The research population is all teachers in region II Pesanggrahan amounted to 141 teachers which are 59 teachers as samples using cluster random sampling method.

The analysis used is multiple linear regression analysis. The results of this research indicate the competence has a positive and significant effect on teacher performance and the work environment also compensation has no positive and significant effect on teacher performance. Simultaneously competence, work environment and compensation have a positive and significant influence on teacher performance.
\end{abstract}

Keywords: Teacher performance, Competence, Work environment, Compensation.

\section{PENDAHULUAN}

Pendidikan merupakan kewajiban bagi semua orang, karena pendidikan memiliki peranan yang sangat penting bagi kehidupan. Melalui pendidikan dapat menjadikan seseorang menjadi pribadi yang berkualitas dan mempunyai sumber daya manusia yang tinggi. Pada proses pendidikan secara keseluruhan, guru merupakan faktor penentu yang sangat dominan dalam pendidikan karena guru adalah pendidik professional dengan tugas utama mendidik, mengajar, membimbing, mengarahkan, melatih, menilai dan mengevaluasi peserta didik. Seorang guru yang profesional dituntut dengan sejumlah persyaratan antara lain memiliki kualifikasi pendidikan profesi, kompetensi keilmuan sesuai bidang yang ditekuninya, kemampuan berkomunikasi yang baik dengan anak didiknya, mempunyai jiwa kreatif dan produktif, mempunyai etos kerja dan komitmen yang tinggi terhadap profesinya serta selalu melakukan pengembangan diri secara terus menerus. Namun demikian dalam pelaksanaannya masih sering ditemukan keterbatasan baik secara individu dan institusi.

Keberhasilan penyelenggara dan pengelolaan pendidikan di sekolah juga merupakan cermin kinerja yang baik. Berdasarkan temuan pada guru TK di wilayah II Pesanggrahan kinerja guru dipengaruhi oleh kompetensi, lingkungan kerja dan kompensasi. Apabila kompetensi yang dimiliki guru baik maka kinerjanya akan meningkat dan sebaliknya, begitu pula dengan lingkungan kerja apabila kondisi di sekitar guru bekerja nyaman dan menunjang fasilitas belajar maka keberhasilan akan materi kepada siswa juga maksimal dan sebaliknya serta apabila 
kompensasi yang diterima oleh guru layak dan cukup akan membuat guru semakin semangat dalam bekerja dan lebih menunjukkan loyalitasnya begitu sebaliknya.

\section{KAJIAN TEORI}

Menurut Kasmir (2016:182) dilihat dari arti kata kinerja berasal dari kata performance. Secara sederhana kinerja diartikan sebagai hasil kerja dan perilaku kerja yang telah dicapai dalam menyelesaikan tugas-tugas dan tanggung jawab yang diberikan dalam suatu periode tertentu. Menurut Supardi (2013) kinerja guru merupakan kemampuan seorang guru dalam melaksanakan tugas pembelajaran di madrasah dan bertangung jawab atas peserta didik di bawah bimbingannya dengan meningkatkan prestasi belajar peserta didik. Oleh karena itu kinerja guru dapat diartikan sebagai suatu kondisi yang menunjukkan kemampuan seorang guru dalam menjalankan tugasnya di madrasah serta menggambarkan adanya suatu perbuatan yang ditampilkan guru dalam satu atau selama melakukan aktivitas pembelajaran. Kinerja guru dapat diukur melalui Kulaitas Kerja, Kecepatan/ketepatan kerja, Inisiatif dalam kerja, Kemampuan kerja, Komunikasi.

Musfah (2011:27) menyatakan bahwa kompetensi adalah kumpulan pengetahuan, perilaku dan keterampilan yang harus dimiliki oleh guru untuk mencapai tujuan pembelajaran dan pendidikan. Kompetensi diperoleh melalui pendidikan, pelatihan dan belajar mandiri dengan memanfaatkan sumber belajar. Menurut Badan Standar Nasioanal Pendidikan (2006) dalam Yufiarti dan Titi (2010) dinyatakan bahwa kompetensi sebagai agen pembelajaran pada jenjang anak usia dini meliputi empat komponen yaitu: kompetensi pedagogik, kompetensi kepribadian, kompetensi sosial dan kompetensi professional.

Menurut Kasmir (2016:192) Lingkungan kerja merupakan suasana atau kondisi di sekitar lokasi tempat bekerja. Lingkungan kerja dapat berupa ruangan, layout, saran dan prasarana serta hubungan kerja dengan sesama rekan kerja. Lingkungan Kerja dibagi menjadi dua yaitu lingkungan kerja fisik dan non fisik. Menurut Sedarmayanti (2009:31) lingkungan kerja fisik adalah semua keadaan berbentuk fisik yang terdapat di sekitar tempat kerja yang dapat mempengaruhi karyawan baik secara langsung maupun secara tidak langsung. Sedangkan lingkungan kerja nonfisik adalah semua keadaan yang terjadi berkaitan dengan hubungan kerja, baik hubungan dengan atasan maupun dengan rekan kerja, ataupun hubungan dengan bawahan.

Dijelaskan oleh Kasmir (2016) Kompensasi merupakan balas jasa yang diberikan perusahaan kepada karyawannya, baik yang bersifat keuangan maupun non keuangan. Artinya perusahaan akan memeberikan balas jasa kepada seluruh karyawan yang terlibat di dalamnya. Kompensasi dibagi menjadi dua yakni kompensasi langusng (gaji, upah, insentif, bonus, komisi) dan tidak langsung (tunjangan-tunjangan, penghargaan, rekreasi/liburan).

\section{Kerangka Berfikir}

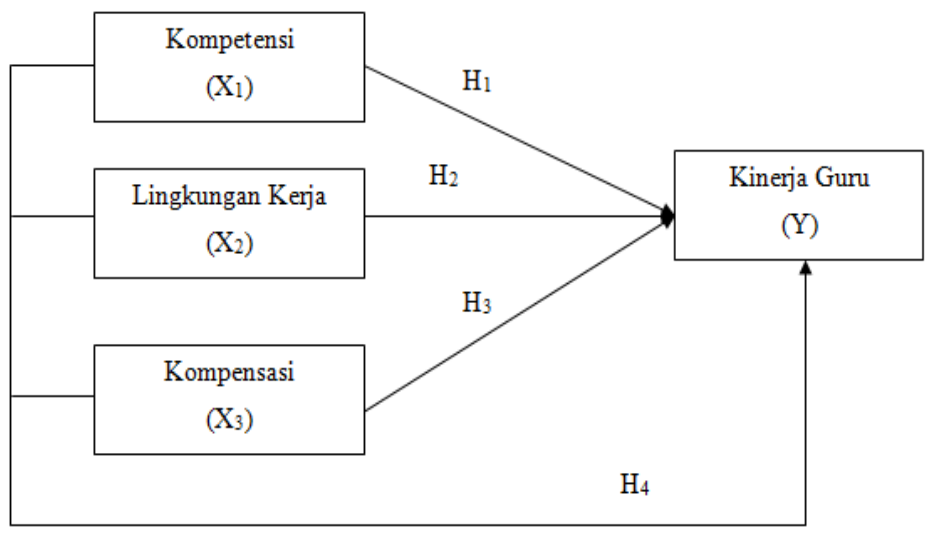




\section{Hipotesis}

Hipotesis 1 (Kompetensi terhadap kinerja Guru)

$\mathrm{Ho}_{1}$ : Tidak terdapat pengaruh antara kompetensi terhadap kinerja guru.

$\mathrm{Ha}_{1}$ : Terdapat pengaruh antara kompetensi terhadap kinerja guru.

Hipotesis 2 (Lingkungan Kerja terhadap kinerja Guru)

$\mathrm{Ho}_{2}$ : Tidak terdapat pengaruh antara lingkungan kerja terhadap kinerja guru.

$\mathrm{Ha}_{2}$ : Terdapat pengaruh antara lingkungan kerja terhadap kinerja guru.

Hipotesis 3 (Kompensasi terhadap kinerja Guru)

$\mathrm{Ho}_{3}$ : Tidak terdapat pengaruh antara kompensasi terhadap kinerja guru.

$\mathrm{Ha}_{3}$ : Terdapat pengaruh antara kompensasi terhadap kinerja guru.

Hipotesis 4 (Kompetensi, Lingkungan Kerja dan Kompetensi terhadap kinerja Guru)

$\mathrm{Ho}_{4}$ : Tidak terdapat pengaruh antara kompetensi, lingkungan kerja dan kompensasi secara simultan terhadap kinerja guru.

Ha4: Terdapat pengaruh antara kompetensi, lingkungan kerja dan kompensasi secara simultan terhadap kinerja guru.

\section{METODE PENELITIAN}

\section{a. Tempat dan Waktu Penelitian}

Penelitian ini dilaksanakan pada beberapa Sekolah Taman Kanak-Kanak (TK) di Wilayah II Kecamatan Pesanggrahan, Jakarta Selatan, mulai dari bulan Maret sampai dengan bulan Agustus 2017. Penelitian memilih Guru Taman Kanak-Kanak (TK) sebagai objek penelitian.

\section{b. Sumber dan Teknik Pengumpulan Data}

Data yang digunakan adalah data primer yang peneliti olah kembali dan data sekunder berupa data dokumenter. Teknik pengumpulan data dengan Penelitian Kepustakaan (Library Research) yaitu dengan mempelajari dan membaca buku-buku, literatur literatur dan bahan buku bacaan lain yang berhubungan dengan permasalahan yang diteliti, dengan Penelitian Lapangan (Field Research) yang meliputi kuesioner, wawancara dan observasi.

\section{c. Populasi dan Sampel}

Sekumpulan objek yang akan dijadikan sebagai bahan penelitian dengan ciri mempunyai karakteristik yang sama pada penelitian ini atau populasinya adalah 141 guru TK. Karena besarnya populasi dan luasanya wilayah penelitian maka pengambilan sampel menggunakan teknik Cluster Random Sampling yaitu cara mengambil sampel dari populasi secara acak di mana populasi terbagi dalam kelompok-kelompok (Soewadji 141:2012). Cluster ditentukan berdasarkan kedekatan wilayah yaitu sebanyak 7 cluster dan diperoleh sampel sebanyak 59 guru TK.

\section{HASIL PENELITIAN}

\section{Analisis Regresi Linier Berganda}

\section{Tabel 1. Analisis Regresi Linier Berganda} Coefficients $^{a}$

\begin{tabular}{|l|r|r|r|r|r|}
\hline \multirow{2}{*}{ Model } & \multicolumn{2}{|c|}{ Unstandardized Coefficients } & \multicolumn{1}{c|}{$\begin{array}{c}\text { Standardized } \\
\text { Coefficients }\end{array}$} & \multicolumn{1}{c|}{ Sig. } & \\
\cline { 2 - 4 } & \multicolumn{1}{|c|}{$\mathrm{B}$} & Std. Error & \multicolumn{1}{c|}{ Beta } & & \\
\hline \multirow{2}{*}{ (Constant) } & 28.820 & 6.894 & & 4.180 & .000 \\
Kompetensi & .600 & .102 & .726 & 5.882 & .000 \\
LingkunganKerja & .157 & .204 & .117 & .766 & .447 \\
Kompensasi & -.070 & .105 & -.081 & -.666 & .508 \\
\hline
\end{tabular}

a. Dependent Variable: KinerjaGuru 
Berdasarkan tabel 1, diperoleh persamaan regresi berganda sebagai berikut :

$$
\mathrm{Y}=28,820+0,600 \mathrm{X}_{1}+0,157 \mathrm{X}_{2}-0,070 \mathrm{X}_{3}+\mathrm{e}
$$

Keterangan :

$\mathrm{Y}=$ Kinerja guru

$\mathrm{X} 1=$ Kompetensi

$\mathrm{X} 2$ = Lingkungan kerja

$\mathrm{X} 3$ = Kompensasi

Persamaan regresi tersebut mempunyai makna sebagai berikut:

1. Konstanta $=28,820$

Jika variabel Kompetensi, Lingkungan Kerja dan Kompensasi dianggap sama dengan nol, maka variabel Kinerja guru sebesar 28,820. Atau jika tidak ada pengaruh dari variabel - variabel bebas Kompetensi, Lingkungan Kerja dan Kompensasi maka kinerja guru tidak mengalami perubahan.

2. Koefisien Kompetensi $=0,600$

Jika variabel Kompetensi mengalami kenaikan sebesar satu poin, sementara Lingkungan Kerja dan Kompensasi dianggap tetap, maka akan menyebabkan kenaikan kinerja guru sebesar 0,600

3. Koefisien Lingkungan kerja $=0,157$

Jika variabel Lingkungan Kerja mengalami kenaikan sebesar satu poin, sementara Kompetensi dan Kompensasi dianggap tetap, maka akan menyebabkan kenaikan kinerja guru sebesar 0,157.

4. Koefisien Kompensasi $=-0,070$

Jika variabel Kompensasi mengalami kenaikan sebesar satu poin, sementara Kompetensi dan Lingkungan kerja dianggap tetap, maka akan menyebabkan penurunan kinerja guru sebesar 0,070 .

\section{Uji Hipotesis}

\section{Uji Parsial (Uji t)}

Uji t digunakan untuk mengetahui apakah variabel independent secara parsial berpengaruh terhadap variabel dependen. Kriteria pengujiannya adalah:

Ho diterima jika $\mathrm{t}$ tabel $\leq \mathrm{t}$ hitung $\leq \mathrm{t}$ tabel atau sig. $>0,05$

Ho ditolak jika $t$ hitung $\geq \mathrm{t}$ tabel atau $\mathrm{t}$ hitung $>\mathrm{t}$ tabel atau sig. $<0,05$.

Tabel 2. Uji t

Coefficients $^{\mathrm{a}}$

\begin{tabular}{|l|r|r|r|r|r|}
\hline \multirow{2}{*}{ Model } & \multicolumn{2}{|c|}{ Unstandardized Coefficients } & \multicolumn{1}{c|}{$\begin{array}{c}\text { Standardized } \\
\text { Coefficients }\end{array}$} & \multicolumn{1}{c|}{ Sig. } \\
\cline { 2 - 4 } & \multicolumn{1}{|c|}{$\mathrm{B}$} & \multicolumn{1}{c|}{ Std. Error } & \multicolumn{1}{c|}{ Beta } & & \\
\hline \multirow{2}{*}{ (Constant) } & 28.820 & 6.894 & & 4.180 & .000 \\
Kompetensi & .600 & .102 & .726 & 5.882 & .000 \\
LingkunganKerja & .157 & .204 & .117 & .766 & .447 \\
Kompensasi & -.070 & .105 & -.081 & -.666 & .508 \\
\hline
\end{tabular}

a. Dependent Variable: KinerjaGuru

Sumber: Data diolah Peneliti (2017)

Berdasarkan tabel 2 diatas dapat disimpulkan mengenai pengujian hipotesis secara parsial yang telah dibuat sebagai berikut :

\section{Hipotesis 1 :}

$\mathrm{Ho}_{1}$ : Tidak terdapat pengaruh antara kompetensi terhadap kinerja guru. 
$\mathrm{Ha}_{1}$ : Terdapat pengaruh antara kompetensi terhadap kinerja guru.

Hasil uji hipotesis 1 dapat dilihat variabel kompetensi mempunyai nilai (t hitung) 5,882 > 2,004 (t tabel) dengan signifikansi $0,000<0,05$. Hal ini menyimpulkan bahwa $\mathrm{Ha}_{1}$ diterima sehingga dapat dikatakan bahwa kompetensi berpengaruh positif dan signifikan terhadap kinerja guru.

\section{Hipotesis 2 :}

$\mathrm{Ho}_{2}$ : Tidak terdapat pengaruh antara lingkungan kerja terhadap kinerja guru

$\mathrm{Ha}_{2}$ : Terdapat pengaruh antara lingkungan kerja terhadap kinerja guru

Hasil uji hipotesis 2 dapat dilihat variabel lingkungan kerja mempunyai nilai (t hitung) $0,766<2,004$ ( t tabel) dengan signifikansi 0,447 >0,05. Hal ini menyimpulkan bahwa $\mathrm{Ho}_{2}$ diterima sehingga dapat dikatakan bahwa lingkungan kerja tidak berpengaruh positif dan tidak signifikan terhadap kinerja guru.

\section{Hipotesis 3 :}

$\mathrm{Ho}_{3}$ : Tidak terdapat pengaruh antara kompensasi terhadap kinerja guru

$\mathrm{Ha}_{3}$ : Terdapat pengaruh antara kompensasi terhadap kinerja guru

Hasil uji hipotesis 3 dapat dilihat variabel kompensasi mempunyai nilai (t hitung) $-0,081<$ 2,004 (t tabel) dengan signifikansi 0,508 $>0,05$. Hal ini menyimpulkan bahwa $\mathrm{Ho}_{3}$ diterima sehingga dapat dikatakan bahwa kompensasi tidak berpengaruh positif dan tidak signifikan terhadap kinerja guru.

\section{Uji F (Simultan)}

Uji $F$ digunakan untuk menguji apakah varibel independent secara simultan berpengaruh terhadap variabel dependen. Uji $\mathrm{F}$ dapat dilakukan dengan membandingkan $\mathrm{F}$ hitung dengan $\mathrm{F}$ tabel. Jika $\mathrm{F}$ hitung $>\mathrm{F}$ tabel maka Ho ditolak dan jika $\mathrm{F}$ hitung $<\mathrm{F}$ tabel maka Ho diterima.

Tabel 3. Uji F ANOVA $^{\mathrm{a}}$

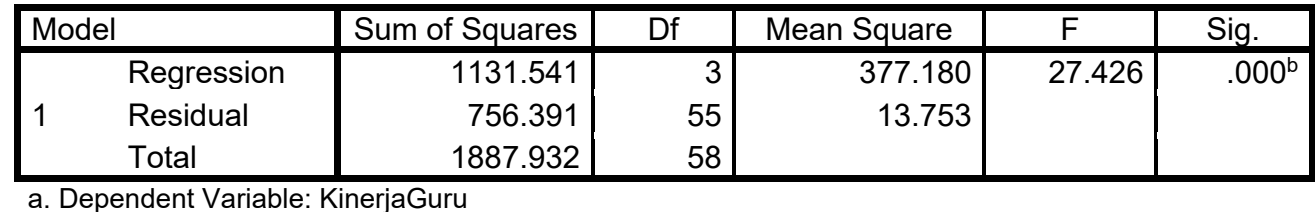

b. Predictors: (Constant), Kompensasi, Kompetensi, LingkunganKerja

Sumber: Data diolah Peneliti (2017)

Pada tabel di atas diperoleh nilai $\mathrm{F}$ hitung 27,426 $>\mathrm{F}$ tabel 2,77 dengan tingkat signifikasi $0,000<0,05$. Karena probabilitas signifikan lebih kecil dari 0,05 maka $\mathrm{Ho}_{4}$ ditolak dan $\mathrm{Ha}_{4}$ diterima. Maka dengan kata lain variabel independent Kompetensi, Lingkungan Kerja dan Kompensasi disini mampu menjelaskan besarnya variabel dependen Kinerja karyawan. Hal ini menunjukan bahwa $\mathrm{Ha}_{4}$ yang menyatakan bahwa ada pengaruh Kompetensi, Lingkungan Kerja dan Kompensasi secara simultan terhadap Kinerja guru diterima.

\section{Analisa Koefisien Determinasi}

Koefisien determinasi digunakan untuk menjelaskan proporsi variabel dependent yang mampu dijelaskan oleh variabel bebasnya (independent) baik secara parsial maupun simultan.

Tabel 4. Koefisien Determinasi Simultan $\left(\mathbf{R}^{2}\right)$ Model Summary ${ }^{\mathrm{b}}$ 


\begin{tabular}{|l|r|r|r|r|}
\hline Model & \multicolumn{1}{|c|}{$\mathrm{R}$} & R Square & Adjusted R Square & \multicolumn{2}{|c|}{$\begin{array}{c}\text { Std. Error of the } \\
\text { Estimate }\end{array}$} \\
\hline 1 & $.774^{\mathrm{a}}$ & .599 & .578 & 3.708 \\
\hline
\end{tabular}

a. Predictors: (Constant), Kompensasi, Kompetensi, LingkunganKerja

b. Dependent Variable: KinerjaGuru

Pada tabel 4. diperoleh nilai Adjusted $R$ Square $=0,578=57,8 \%$ ini berarti variabel bebas Kompetensi, Lingkungan Kerja dan Kompensasi secara bersama-sama mempengaruhi variabel dependen Kinerja guru sebesar 57,8\% dan sisanya 42,2\% dipengaruhi oleh variabel lain yang tidak masuk dalam penelitian ini.

Tabel 5. Koefisien Determinasi Parsial $\left(\mathbf{r}^{2}\right)$

\begin{tabular}{|c|c|c|c|c|c|c|}
\hline \multirow{2}{*}{\multicolumn{2}{|c|}{ Model }} & \multicolumn{2}{|c|}{$\begin{array}{c}\text { Unstandardized } \\
\text { Coefficients }\end{array}$} & $\begin{array}{c}\text { Standardized } \\
\text { Coefficients } \\
\end{array}$ & \multirow[t]{2}{*}{$\mathrm{t}$} & \multirow[t]{2}{*}{ Sig. } \\
\hline & & $B$ & Std. Error & Beta & & \\
\hline \multirow{4}{*}{1} & (Constant) & 28.820 & 6.894 & & 4.180 & .000 \\
\hline & Kompetensi & .600 & .102 & .726 & 5.882 & .000 \\
\hline & LingkunganKerja & .157 & .204 & .117 & .766 & .447 \\
\hline & Kompensasi & -.070 & .105 & -.081 & -.666 & .508 \\
\hline
\end{tabular}

Berdasarkan tabel di atas, diketahui besarnya Correlations Partial $\left(\mathrm{r}^{2}\right)$ Kompetensi adalah $72,6 \%$, besarnya pengaruh Lingkungan Kerja adalah $11,7 \%$, besarnya pengaruh Kompensasi adalah -8,1\%. Hal ini menunjukkan bahwa variabel Kompetensi memberikan pengaruh paling besar terhadap kinerja karyawan dibandingkan variabel Lingkungan Kerja dan Kompensasi.

\section{Analisa Korelasi}

Analisa korelasi digunakan untuk mengetahui hubungan antara dua variabel, baik variabel bebas maupun variabel terikat. Dalam perhitungan korelasi akan didapat koefisien korelasi yang menunjukan keeratan hubungan antara dua variabel tersebut. Nilai koefisien korelasi berkisar antara 0 sampai 1 atau 0 sampai -1, nilai semakin mendekati 1 atau -1, maka hubungan semakin erat, jika mendekati 0 , maka hubungan semakin lemah.

Tabel 6. Analisa Korelasi Correlations

\begin{tabular}{|ll|r|r|r|r|}
\hline & & KinerjaGuru & Kompetensi & $\begin{array}{r}\text { LingkunganK } \\
\text { erja }\end{array}$ & Kompensasi \\
\hline \multirow{3}{*}{ KinerjaGuru } & Pearson Correlation & 1 & $.771^{* *}$ & $.583^{* *}$ & $.354^{* *}$ \\
& Sig. (2-tailed) & & .000 & .000 & .006 \\
& $\mathrm{~N}$ & 59 & 59 & 59 & 59 \\
& Pearson Correlation & $.771^{* *}$ & 1 & $.721^{* *}$ & $.484^{* *}$ \\
Kompetensi & Sig. (2-tailed) & .000 & .000 & .000 \\
\cline { 2 - 6 } & $\mathrm{N}$ & 59 & 59 & 59 & 59 \\
& Pearson Correlation & $.583^{* *}$ & $.721^{* *}$ & 1 & $.708^{* *}$ \\
LingkunganKerja & Sig. (2-tailed) & .000 & .000 & .000 \\
& $\mathrm{~N}$ & 59 & 59 & 59 & 59 \\
Kompensasi & Pearson Correlation & $.354^{* *}$ & $.484^{* *}$ & $.708^{* *}$ & 1
\end{tabular}




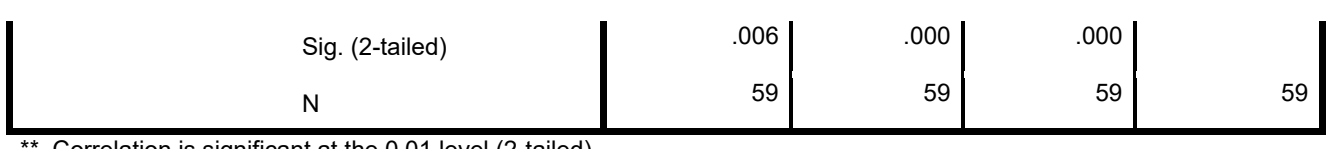

Sumber: Data diolah Peneliti (2017)

Berdasarkan tabel 6. diatas dapat dijelaskan bahwa :

1. Korelasi antara kinerja guru dengan kompetensi didapat nilai koefisien sebesar 0,771. Karena koefisien mendekati 1, maka dapat disimpulkan bahwa antara kinerja guru dengan kompetensi memiliki hubungan yang erat.

2. Korelasi antara kinerja guru dengan lingkungan kerja didapat nilai koefisien sebesar 0,583. Karena koefisien mendekati 1, maka dapat disimpulkan bahwa antara kinerja guru dengan lingkungan kerja memiliki hubungan yang erat.

3. Korelasi antara kinerja guru dengan kompensasi didapat nilai koefisien sebesar 0,354. Karena koefisien mendekati 0, maka dapat disimpulkan bahwa antara kinerja guru dengan kompensasi memiliki hubungan yang lemah.

Berdasarkan penjelasan diatas dapat disimpulkan bahwa korelasi antara kinerja guru dengan kompetensi didapat nilai koefisien sebesar 0,771. Karena koefisien kompetensi paling mendekati 1, maka dapat disimpulkan bahwa antara kinerja guru dengan kompetensi memiliki hubungan yang paling erat.

\section{PEMBAHASAN}

\section{Kompetensi terhadap Kinerja Guru}

Berdasarkan hasil penelitian di atas dapat dikatakan bahwa variabel Kompetensi mempengaruhi variabel Kinerja Guru dengan nilai $t$ hitung positif untuk variabel kompetensi 5,882 lebih besar dari nilai t tabel sebesar 2,004 dengan tingkat signifikansi $0,000<0,05$. Artinya dapat disimpulkan bahwa $\mathrm{Ha}_{1}$ diterima yang berarti variable Kompetensi berpengaruh positif dan signifikan secara parsial terhadap Kinerja Guru TK di Wilayah II Kec. Pesanggrahan, di mana besarnya pengaruh Kompetensi sebesar 72,6\% terhadap Kinerja Guru.

Hasil penelitian ini sesuai dengan teori Kasmir (2016:189) yang menyatakan semakin seseorang memiliki kemampuan (kompetensi) dan keahlian maka akan dapat menyelesaikan pekerjannya secara benar, sesuai dengan yang telah ditetapkan. Artinya karyawan yang memiliki kemampuan (kompetensi) yang lebih baik, maka akan memberikan kinerja baik pula, demikian sebaliknya bagi karyawan yang tidak memiliki kemampuan (kompetensi) untuk menyelesaikan pekerjannya secara benar maka akan memberikan hasil yang kurang baik akhirnya menunjukkan kinerja yang kurang baik. Oleh karena itu, upaya meningkatkan kinerjanya, guru harus meningkatkan pengetahuan dan pemahaman tentang kompetensi pedagogik, kompetensi kepribadian, kompetensi sosial, dan kompetensi kepribadian salah satunya dengan diikutsertakannya guru dalam setiap pelatihan kompetensi. Kemudian kompetensi-kompetensi tersebut diterapkan dalam pelaksanakan tugas sebagai seorang guru.

\section{Lingkungan Kerja terhadap Kinerja Guru}

Berdasarkan hasil penelitian di atas dapat dikatakan bahwa variabel Lingkungan Kerja tidak mempengaruhi variabel Kinerja Guru dengan nilai thitung positif untuk variable lingkungan kerja 0,766 lebih kecil dari nilai $t$ tabel sebesar 2,004 dengan tingkat signifikansi 0,447 > 0,05 . Artinya dapat disimpulkan bahwa $\mathrm{Ho}_{2}$ diterima yang berarti variable Lingkungan Kerja tidak berpengaruh positif dan signifikan secara parsial terhadap Kinerja Guru TK di Wilayah II Kec. Pesanggrahan, di mana besarnya pengaruh Lingkungan Kerja sebesar $11,7 \%$ terhadap Kinerja Guru. 
Namun hasil penelitian tidak sesuai pada teori Kasmir (2016:192) yang menyatakan jika lingkungan kerja dapat membuat suasana nyaman dan memberikan ketenangan maka akan membuat suasana kerja menjadi kondusif, sehingga dapat meningkatkan hasil kerja seseorang menjadi lebih baik, karena lingkungan tanpa gangguan. Namun sebaliknya jika suasana atau kondisi lingkungan kerja tidak memberikan kenyamanan atau ketenangan, maka akan berakibat suasana kerja menjadi terganggu yang pada akhirnya akan mempengaruhinya dalam bekerja. Dapat disimpulkan bahwa dengan fasilitas bermain siswa yang kurang memadai dan hubungan dengan rekan kerja dan seluruh anggota kurang harmonis, Kinerja Guru TK di Wilayah II Kec. Pesanggrahan tetap stabil dan masih terbilang baik. Karena guru masih memiliki kompetensi yang baik dalam hal mampu menggunakan berbagai metode atau alat pembelajaran yang lebih beragam dilihat dari pendidikan terakhir guru dominan adalah S1, sehingga mampu membuat siswa menjadi lebih interaktif dan antusias belajar walaupun dengan sarana prasarana yang minim.

\section{Kompensasi terhadap Kinerja Guru}

Berdasarkan hasil penelitian di atas dapat dikatakan bahwa variabel Kompensasi tidak mempengaruhi variabel Kinerja Guru dengan nilai $t$ hitung negatif untuk variabel kompensasi -0,081 lebih kecil dari nilai t tabel sebesar 2,004 dengan tingkat signifikansi $0,508>0,05$. Artinya dapat disimpulkan bahwa $\mathrm{Ho}_{3}$ diterima yang berarti variabel kompensasi tidak berpengaruh positif dan signifikan secara parsial terhadap Kinerja guru TK di Wilayah II Kec. Pesanggrahan, di mana besarnya pengaruh Kompensasi sebesar $8,1 \%$ terhadap Kinerja Guru.

Namun hasil penelitian tidak sesuai dengan teori Kasmir (2016:255) yang menjelaskan bahwa kinerja karyawan memiliki hubungan dengan pemberian kompensasi. Artinya jika kompensasi yang diberikan secara layak dan wajar maka kinerja karyawan akan meningkat, dan berdampak kepada variabel lainnya. Namun jika kompensasi yang dilakukan tidak dibayar secara wajar dan layak maka kinerja karyawan akan turun. Dapat disimpulkan bahwa walaupun gaji dan upah yang diterima belum terpenuhi, masih jarangnya pemberian bonus atau insentif serta penghargaan yang masih kurang bagi para guru, kinerja guru tidak ikut menurun dan cenderung baik serta dengan didominasi guru usia pada rentang 30-40 tahun dengan lama bekerja di rentang 10-20 tahun dapat dilihat bahwa mayoritas guru bekerja karena dasar pengabdian dan loyalitas kepada sekolah dengan tidak semata mengharapkan kompensasi yang besar.

\section{Kompetensi, Lingkungan Kerja dan Kompensasi terhadap Kinerja Guru}

Berdasarkan hasil penelitian di atas dapat dikatakan bahwa variabel kompetensi, lingkungan kerja dan kompensasi secara simultan mempengaruhi variabel Kinerja Guru dengan nilai $\mathrm{F}$ hitung positif 27,426 lebih besar dari nilai $\mathrm{F}$ tabel sebesar 2,77 dengan tingkat signifikansi $0,000<0,05$. Artinya dapat disimpulkan bahwa $\mathrm{Ha}_{4}$ diterima yang berarti variabel kompetensi, lingkungan kerja dan kompensasi berpengaruh positif dan signifikan secara simultan terhadap Kinerja guru TK di Wilayah II Kec. Pesanggrahan. Setiap kenaikan variabel bebas akan diikuti oleh kenaikan variable terikat. Berdasarkan nilai Adjusted $R$ Square pada hasil uji koefisien determinasi $\left(\mathrm{R}^{2}\right)$ Simultan diperoleh hasil 0,578 sehingga dapat disimpulkan bahwa variabel kompetensi, lingkungan kerja dan kompensasi berpengaruh terhadap kinerja karyawan sebesar 57,8\% dan sisanya 42,2\% dipengaruhi oleh variabel lain yang tidak masuk dalam penelitian ini. Sehingga jika variabel kompetensi, lingkungan kerja dan kompensasi dapat ditingkatkan secara bersama-sama maka hasil kinerja guru akan lebih maksimal.

\section{KESIMPULAN DAN SARAN}




\section{Kesimpulan}

1. Terdapat pengaruh secara parsial Kompetensi terhadap Kinerja Guru. Dapat disimpulkan bahwa semakin baik kompetensi maka semakin baik pula kinerja guru dan sebaliknya semakin buruk kompetensi maka semakin buruk kinerja guru.

2. Tidak terdapat pengaruh secara parsial Lingkungan Kerja terhadap Kinerja Guru. Dapat disimpulkan bahwa semakin baik atau buruk lingkungan kerja tidak mempengaruhi kinerja guru.

3. Tidak terdapat pengaruh secara parsial Kompensasi terhadap Kinerja Guru. Dapat disimpulkan bahwa semakin tinggi atau rendah kompensasi tidak mempengaruhi kinerja guru.

4. Terdapat pengaruh secara simultan antara variabel Kompetensi, Lingkungan Kerja, Kompensasi terhadap Kinerja Guru. Dapat disimpulkan bahwa jika kompetensi, lingkungan kerja dan kompensasi ditingkatkan secara bersama-sama maka kinerja guru akan meningkat.

\section{Saran}

1. Bagi Penelitian Mendatang.

Bagi peneliti yang akan datang diharapkan dapat memperbesar jumlah sampel yang mewakili penelitiannya sehingga mampu memberikan gambaran yang lebih luas tentang masalah penelitian yang diteliti.

2. Bagi Pihak Sekolah.

Bagi pihak sekolah diharapkan dapat memberikan kesempatan yang lebih besar kepada para guru untuk mengikuti berbagai pelatihan kompetensi yang dapat menunjang kinerjanya. Serta agar kinerja lebih maksimal dapat memberikan kompensasi seperti berupa penghargaan atas loyalitas guru dalam melakukan pekerjannya.

\section{DAFTAR PUSTAKA}

Anitia Anggreini Batubara, 2016. Pengaruh Lingkungan Kerja, Kompensasi Dan Komitmen Terhadap Kinerja Guru Madrasah Aliyah Negeri (MAN) Di Kota Medan. Skipsi Universitas Islam Negeri Maulana Malik Ibrahim 2016.

Ar. Nefrida. 2016. Pengaruh Kompetensi Guru Dan Lingkungan Kerja Terhadap Kinerja Guru Sekolah Menengah Kejuruan Negeri I Kota Jambi, Jurnal Pendidikan dan Keguruan Vol.1, No. $1: 3$.

Danang Sunyoto. 2012. Teori, Kuesioner, dan Analisi Data Sumber Daya Manusia (Praktik penelitian), CAPS (Center for Academic Puvlishing Service), Yogyakarta.

Dimas Satya Anindia, 2105. Pengaruh Motivasi, Karakteristik Pekerjaan Dan Keadilan Organisasional Terhadap Kepuasan Kerja Karyawan Perusahaan Beton Di Kantor Pusat Jakarta. Skripsi Universitas Islam Negeri Syarif Hidayatullah Jakarta 2015.

Duwi Priyatno. 2014. SPSS 22 : Pengolahan Data Terpraktis, ANDI, Yogyakarta.

Jejen Musfah. 2011. Peningkatan Kompetensi Guru : Melalui Pelatihan Dan Sumber Belajar Teori Dan Praktik, Kencana. Jakarta.

Jusuf Soewadji. 2012. Pengantar Metodologi Penelitian, Mitra Wacana Media, Jakarta. Kasmir. 2016. Manajemen Sumber Daya Manusia (Teori Dan Praktik), Rajawali Pers, Depok. Lijan Poltak Sinambela. 2014. Metodologi Penelitian Kuantitatif, Graha Ilmu, Yogyakarta.Mega Ayu Rahmawati, 2011. Pengaruh Kompetensi Profesional Guru Dan Motivasi Kerja Terhadap Kinerja Guru Ekonomi SMA Di Kota Tegal. Skripsi Universitas Negeri Semarang 2011.

Nurul Ulfatin, Teguh Triwiyanto. 2016. Manajemen Sumber Daya Manusia Bidang Pendidikan, Rajawali Pers, Depok. 
Nur Abib Asriyanto, 2013. Pengaruh Motivasi Kerja Dan Lingkungan Kerja Terhadap Kinerja Karyawan Cv. Kalika Intergraha Di Semarang. Skripsi Universitas Negeri Semarang 2013.

Peraturan Pemerintah Republik Indonesia, Nomor 27 Tahun 1990 Tentang Pendidikan Prasekolah, Bab I Pasal 1 Ayat (2).

Renny Damayanti, 2017. Pengaruh Motivasi Kerja, Kompensasi, Pelatihan, Karakteristik Kerja Terhadap Prestasi Kerja Guru Di Yayasan Pendidikan SMP-SMK Bina Insani Tangerang. Skripsi Universitas Satya Negara Indonesia 2107.

Rina Oktiyani, Kaman Nainggolan. 2016. Analisis Pengaruh Kompensasi Dan Lingkungan Kerja Terhadap Kinerja Guru Di SMA Negeri 1 Klaten, Ecodemica Vol. IV, No. 2 : 137.

Siti Rohimah, 2013. Pengaruh Kompetensi, Kompensasi, Disiplin Kerja Terhadap Kinerja Dan Kepuasan Kerja Guru SMA Islamic Village Karawaci Tangerang. Skipsi Universitas Esa Unggul 2013.

Supardi. 2013. Kinerja Guru, Rajawali Pers, Depok.

Yufiarti, Titi Chandrawati. 2010. Profesionalitas Guru PAUD, Universitas Terbuka, Jakarta. 